\author{
THE ALCOHOL HISTORY COLLECTION \\ AT THE CENTER OF ALCOHOL STUDIES: \\ A VALUABLE RESOURCE ON AMERICAN \\ TEMPERANCE AND PROHIBITION
}

BY PENNY BOOTH PAGE

Penny Page is the director of information services,
Rutgers University Center of Alcohol Studies

The American temperance movement, which culminated in the thirteenyear "dry" hiatus known as National Prohibition, provides a fascinating look at one of the most colorful eras in our history. By the I830s, American alcohol consumption had peaked at an all-time high of 7.I gallons of absolute alcohol per capita annually ${ }^{\mathrm{I}}$ - more than three times the current consumption rate of 2.18 gallons. ${ }^{2}$ As drunkenness grew, many concerned citizens reacted by forming societies advocating the "temperate" use of alcohol (which generally meant moderate use of beer or wine, but no use of hard liquor). However, as the century progressed, fears arising from industrialization and the growing tide of immigration led most temperance leaders to call for total abstinence from all alcoholic beverages as a means of protecting society from the ravages of drink. The Woman's Crusade of the I870s and the formation of the Woman's Christian Temperance Union (WCTU) and the Anti-Saloon League (ASL) reflected the concerns of Americans across the social spectrum for the protection of the family and the maintenance of social norms based largely on Protestant Christian values (although many Catholics and others shared temperance sympathies as well). The Alcohol History Collection at the Rutgers Center of Alcohol Studies provides a valuable look into the attitudes, events, organizations, and leaders of those times.

\title{
Composition of the Collection
}

There are more than 600 items in the Alcohol History Collection. Most are monographs dating from the mid-nineteenth to the early twentieth century. In many cases, the Center of Alcohol Studies is one of only a few libraries holding these titles. ${ }^{3}$ The oldest original items in the collection are

Journal of the Rutgers University Libraries, Volume LXI, pp. 89-IOI

Copyright 2005 by the Rutgers University Libraries. All rights reserved. 
two medical treatises (one in English, one in French). The French title, Pratique des maladies aigues, ${ }^{4}$ was published in two volumes in 1706 and 1707. The National Library of Medicine holds the only other copy of this second edition in the United States. The British title, A Directory Pbysico-Medical, ${ }^{5}$ was published in London in 1707 as a medical textbook. It provides valuable insight into the medical knowledge of the early eighteenth century. The center also owns a copy of a brief representing one of the very few legal challenges to the constitutionality of the Eighteenth Amendment (National Prohibition). The United States of America v. Lonis E. Thibault ${ }^{6}$ was argued before the U.S. Circuit Court of Appeals in 1930. Attorneys for Mr. Thibault challenged his conviction for violation of the Volstead Act (which enforced prohibition) on the grounds that the methods for adoption of the Eighteenth Amendment were invalid. It is interesting to note that one of the attorneys for the appellant was Selden Bacon, the father of Selden D. Bacon, who became director of the Center of Alcohol Studies in 1950, while it was located at Yale University. Only one other library, New York Public Research Library, lists a copy of this document in its collection.

The collection includes journal runs of the most important temperance and prohibition periodicals: Union Signal (WCTU), American Issue (ASL), The Quarterly Journal of Inebriety (Society for the Study and Cure of Inebriety), and Repeal Review (Repeal Associates, successor to the Association Against the Prohibition Amendment), as well as occasional holdings of the Scientific Temperance Journal (Temperance Education Foundation, an offshoot of the ASL) and the Clipsheet (Methodist Board of Temperance Education). The Quarterly Journal of Inebriety was the first medical journal in the United States to be devoted to the study and cure of inebriety (alcoholism). The center has an almost-complete run of this publication on microfilm. For a look at post-prohibition issues, Repeal Review offers an in-depth view of how individual states and the federal government restructured their alcohol control policies through legislation, taxation, and regulation. The center has a complete bound run of this journal, which was published from I936 to 1965.

There are more than 100 pamphlets from a variety of temperance groups and a collection of original letters and documents (275 pieces, dated I85 II86I) dealing with temperance in New England. In addition to the print materials, the collection includes some artifacts and artwork. There are banners, regalia, and insignia from the Nova Scotia division of the Sons of Temperance (mid-twentieth century). There is also an original set of ten 
temperance posters designed by Dr. John Harvey Kellogg (a member of the cereal products family and an outspoken advocate for healthy living and temperance), which depict the effects of alcohol on various body organs. ${ }^{7}$ Finally, there is a unique teaching packet titled Temperance Tales and the Alcobolic, 8 which was compiled in 1979 for the Journal of Studies on Alcobol. It contains slides, narrative audiotape, and a discussion guide depicting artwork and literature from and about the temperance era.

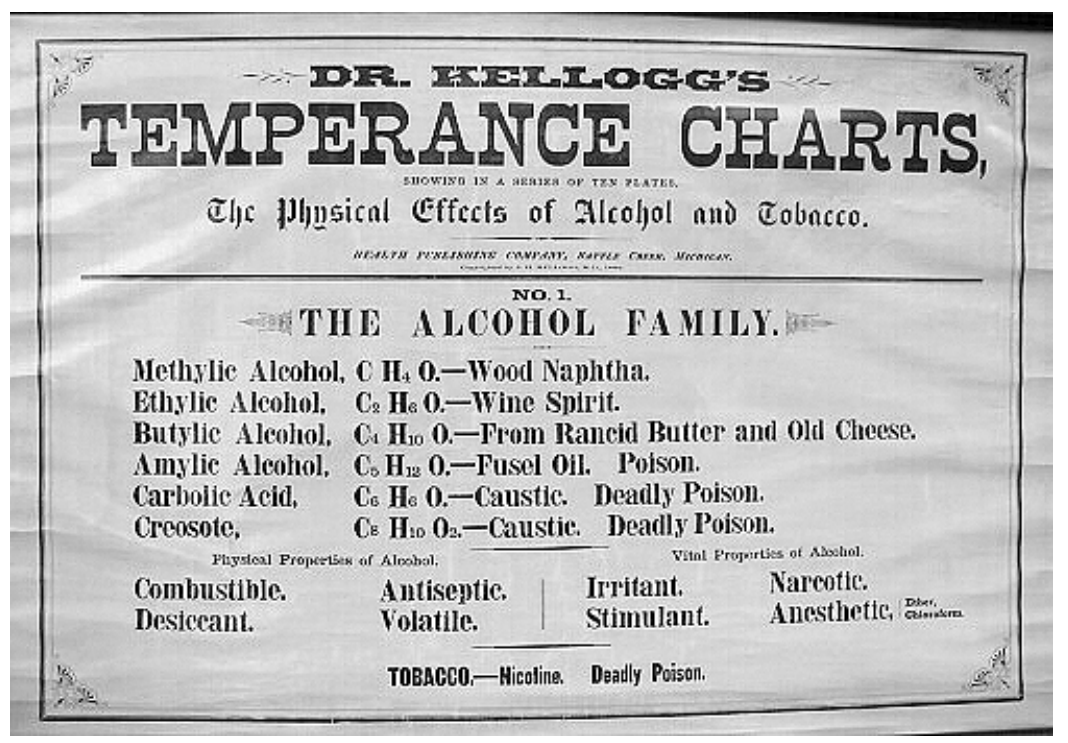

Figure 5.I “The Alcohol Family," plate no. I from Dr. Kellogg's Temperance Charts (from Alcohol History Collection, Alcohol Studies Library)

The subject matter of the collection encompasses a broad range of topics related to temperance and prohibition (primarily U.S.), including effects of alcohol on the body, the family, and society. There are medical treatises, sermons, biographical and autobiographical accounts, and also poetry and fiction. They represent the works of many important temperance and prohibition figures such as Lyman Beecher (theologian and father of abolitionist Harriet Beecher Stowe), Frances Willard (president, WCTU), Ernest Cherrington (editor, American Issue), and Timothy Shay Arthur (whose stories and plays helped bring the temperance message to the masses). There are also materials representing the opposing views of the Association Against the Prohibition Amendment. The materials are housed in a special collections room at the Center of Alcohol Studies, Brinkley and Adele 
Smithers Hall, on the Busch Campus of Rutgers, The State University of New Jersey. They are available for use on-site by students, faculty, and visiting scholars by appointment.

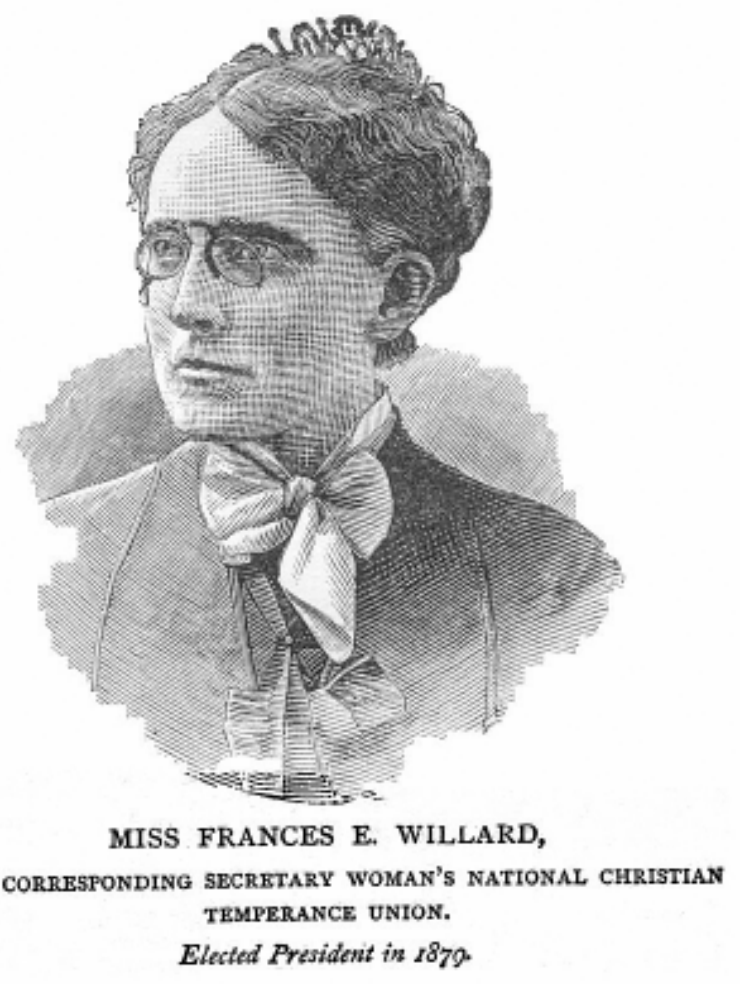

Figure 5.2 "Miss Frances E. Willard," president of the Woman's Christian Temperance Union from 1879 to 1898 (from Alcohol History Collection, Alcohol Studies Library)

\section{Scholarly Importance of the Collection}

What value does the Alcohol History Collection hold for students and scholars? The Alcohol History Collection at Rutgers pulls together materials on all aspects of temperance and prohibition, from a wide range of individuals and organizations, and makes them easily accessible in one place. It offers breadth of coverage and ease of use through an online database of detailed bibliographic records. ' Following repeal of National Prohibition in I933, the next few decades saw the development of an addictions "field" composed of biomedical and psychosocial researchers, clinicians, and social service 
workers. Through the 1970s, the primary focus of this field was on the identification and treatment of addiction as a disease. By the early 1980s, public interest had begun to shift toward the prevention of alcohol and drug problems, especially concerning youth. Once again, grassroots organizations, such as Mothers Against Drunk Driving (MADD), began to lobby the public and the government to legislate a policy that would reduce alcohol and drug use. This "neo-prohibitionist" approach has been particularly popular in antismoking campaigns. Judging from this return to temperance/prohibition rhetoric, one might say, "What goes around, comes around." Historians, sociologists, and others who are interested in social movements and in trends in social behavior and attitudes will find a wealth of material in this collection. In addition, researchers looking into the transition from temperance to research and the development of the modern addictions field will find valuable clues to the beliefs and actions of prominent figures. The Yale Center of Alcohol Studies (predecessor of the Rutgers Center) was at the forefront of this emerging field; thus, materials developed and collected by its leaders are especially important for documenting this evolution.

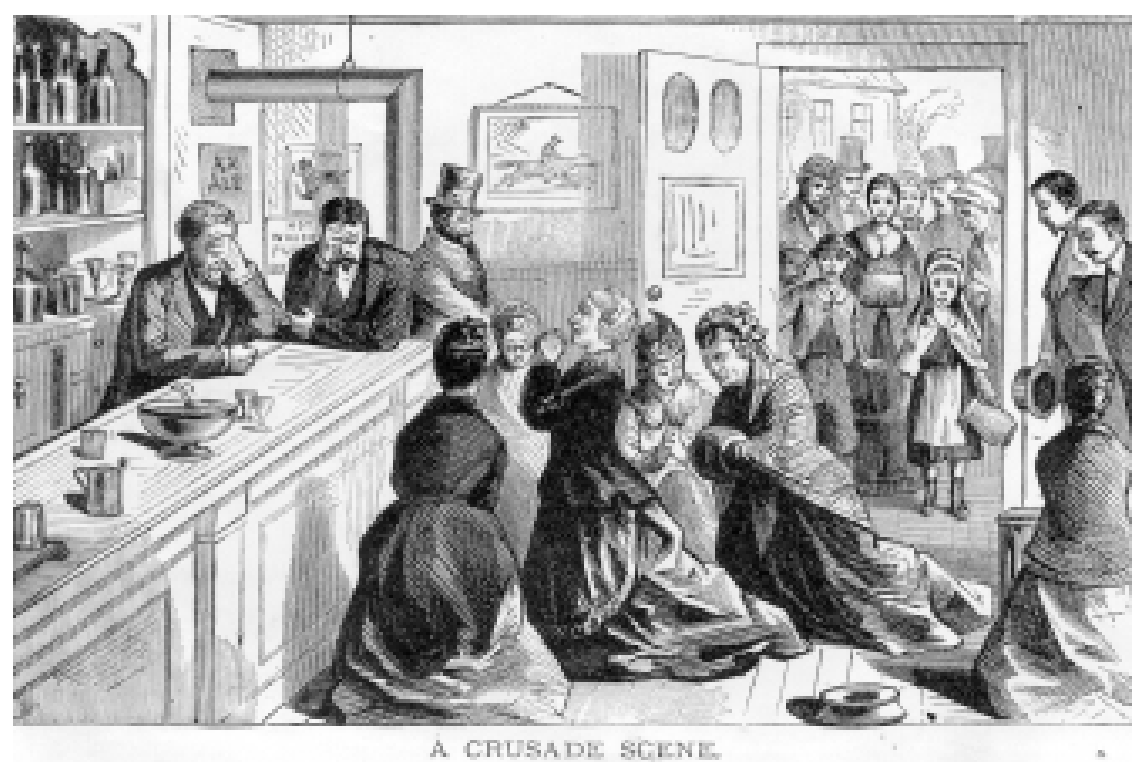

Figure 5.3 "A Crusade Scene" from History of the Woman's Temperance Crusade: A Complete Official History of the Wonderful Uprising of the Christian Women of the United States Against the Liquor Traffic, Which Culminated in the Gospel Temperance Movement, by Annie Wittenmyer (Philadelphia: Office of the Christian Woman, I878). (From Alcohol History Collection, Alcohol Studies Library) 


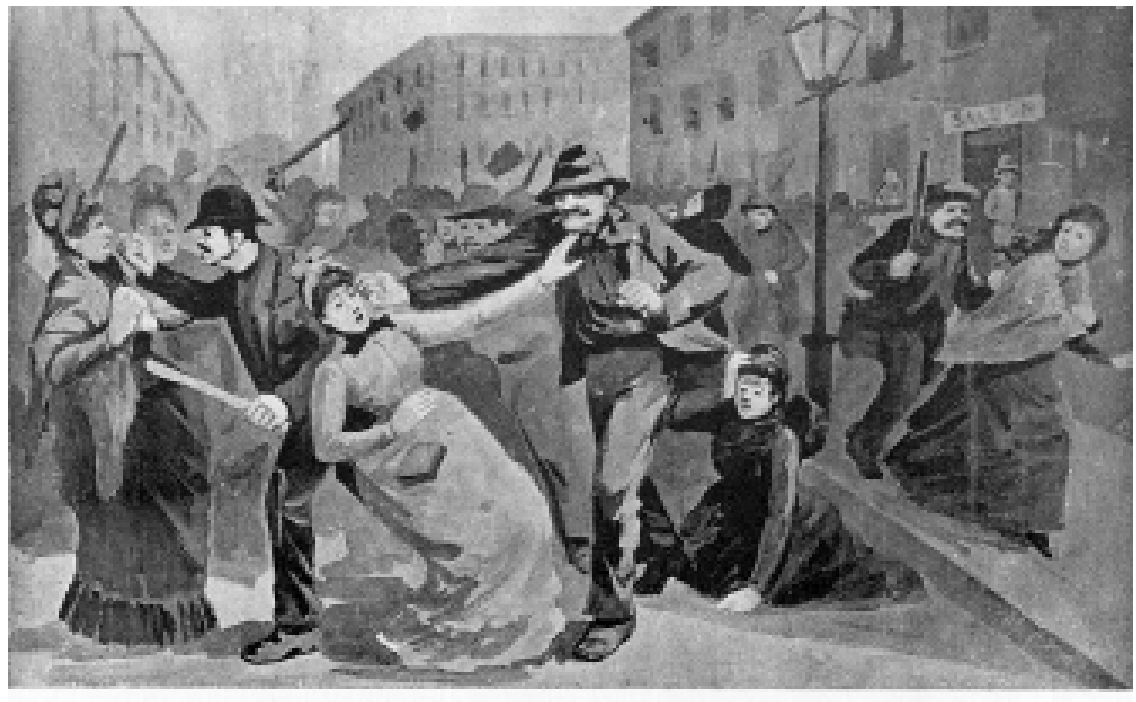

AN ATTACK BY THE MOS ON THE WOMAN CBUSADERS

Figure 5.4 "An Attack by the Mob on the Woman Crusaders," from Broken Fetters, the Light of Ages on Intoxication (I888) (from Alcohol History Collection, Alcohol Studies Library)

The closest relative to the Rutgers collection is the Chester H. Kirk Collection at the Center on Alcohol and Addiction Studies at Brown University, which contains more than 15,000 items on alcoholism and Alcoholics Anonymous. It includes print materials (books, pamphlets, newspapers, posters, dealers' catalogues), audiovisual materials, photographs, engravings, and sheet music. The earliest item is from I493, but most range from the mid-nineteenth to the early twentieth century. The materials are accessible through the Brown University Libraries catalog. The Center on Alcohol and Addiction Studies website ${ }^{\mathrm{IO}}$ provides information about several other historical collections: the Robert Holbrook Smith (co-founder of Alcoholics Anonymous) Collection of books, manuscripts, and memorabilia; the National Council on Alcoholism and Drug Dependence Archives; and the Rutgers Anti-Saloon League Collection of temperance and addiction studies periodicals from foreign-language temperance groups in the United States. This last collection was held by the Rutgers Center of Alcohol Studies from 1982 to 1999, when it was transferred to Brown due to a shortage of storage space and lack of resources to organize the materials.

There are collections of temperance and prohibition materials in other repositories, but most are narrowly focused on a particular organization, 
such as the Anti-Saloon League materials at Westerville, Ohio, ${ }^{\mathrm{II}}$ or an individual, such as the Pierre Dupont papers at the Hagley Museum and Library in Delaware. ${ }^{\text {I2 }}$ Several agencies and institutions have mounted digitized materials on temperance, prohibition, and related aspects, but the number of these online materials is very small, and in many cases they are not easily accessible in succinct collections. For example, both the American Memory Project (Library of Congress) ${ }^{13}$ and the History of Medicine (National Library of Medicine) $)^{14}$ Internet sites contain historical materials on alcohol.

\section{Origins of the Collection}

The Alcohol History Collection did not arise from a conscious decision to collect historical materials. However, as noted earlier, the Center of Alcohol Studies played a key role in the country's transition from prohibition to the modern addictions field. Not surprisingly, many of the center's scholars had an interest in temperance and prohibition issues, and they often acquired books or other documents related to those interests. The center was first established at Yale University in the 1940s, but a formal library was not created until I957. The center moved to Rutgers in the early I960s because Yale no longer wanted to support applied research projects. Before the move, the center's director, Selden D. Bacon, began scouting other possible homes. With a federal grant and support from philanthropist R. Brinkley Smithers, Bacon brought the center to Rutgers in 1962. The first full-time librarian, Adeline Tallau, then began the serious task of locating and moving materials from individual offices to the library. ${ }^{15}$ Over the years, other historical items were donated by center faculty and other researchers and were added to the cataloged book collection.

In 1988, the center accepted the donation of the complete library collection from the headquarters of the National Council on Alcoholism (NCA), the major national organization advocating for treatment of alcoholism as a disease. Included in this collection were nearly 200 historical items dealing with temperance and prohibition. In I989, the center accepted a donation of 100 temperance fiction and nonfiction monographs that had been used in a research project at Moravian College in Pennsylvania.

In 1992, the center library moved into new, expanded quarters in Brinkley and Adele Smithers Hall, adjoining the original center quarters in Christopher 
D. Smithers Hall on Busch Campus. The new library space included a special room designated for the historical materials, which enabled them to be brought together in a single location. In the years since, there have been some additional donations, including pamphlets from the Anti-Saloon League and the Association Against the Prohibition Amendment and the temperance regalia from the Nova Scotia Sons of Temperance, as well as occasional purchases of individual monographs and one collection of letters and papers. To these have been added the slide teaching packet noted earlier (developed by center faculty) as well as copies of artwork and images related to temperance and prohibition. Many of these were collected by historians Mark Lender and James Martin while working on their book Drinking in America: A History. The set of original Kellogg temperance posters was discovered in a wooden box in the library in the early 1980s, but with no documentation on provenance.

\section{Access to the Collection}

By the mid-1990s, the Alcohol History Collection had coalesced into a single entity of more than 500 items housed in a special collections room at the Center of Alcohol Studies. Yet the contents of the collection remained largely unknown to potential users, as well as library staff members. Despite the value of some of the individual items, the collection itself was worth little without bibliographic access.

To remedy this situation, a graduate student assistant developed a bibliographic database using the library's in-house database management software, DBTextworks from Inmagic. She entered detailed bibliographic records for more than one-third of the materials and experimented with adding selected images. Because the database was available only on the library's internal network, we also created a printed finding aid from database records.

The Alcohol History Database provides users and library staff with multiple access points for retrieving materials from the collection. It allows searching by keywords in the author, title, subject, and note fields. Because many of the subject headings for the library's Alcohol Studies Research Database were not appropriate for the historical materials, we used Library of Congress subject headings and modified them where necessary. Whenever possible, subject headings and descriptive information were taken from records 


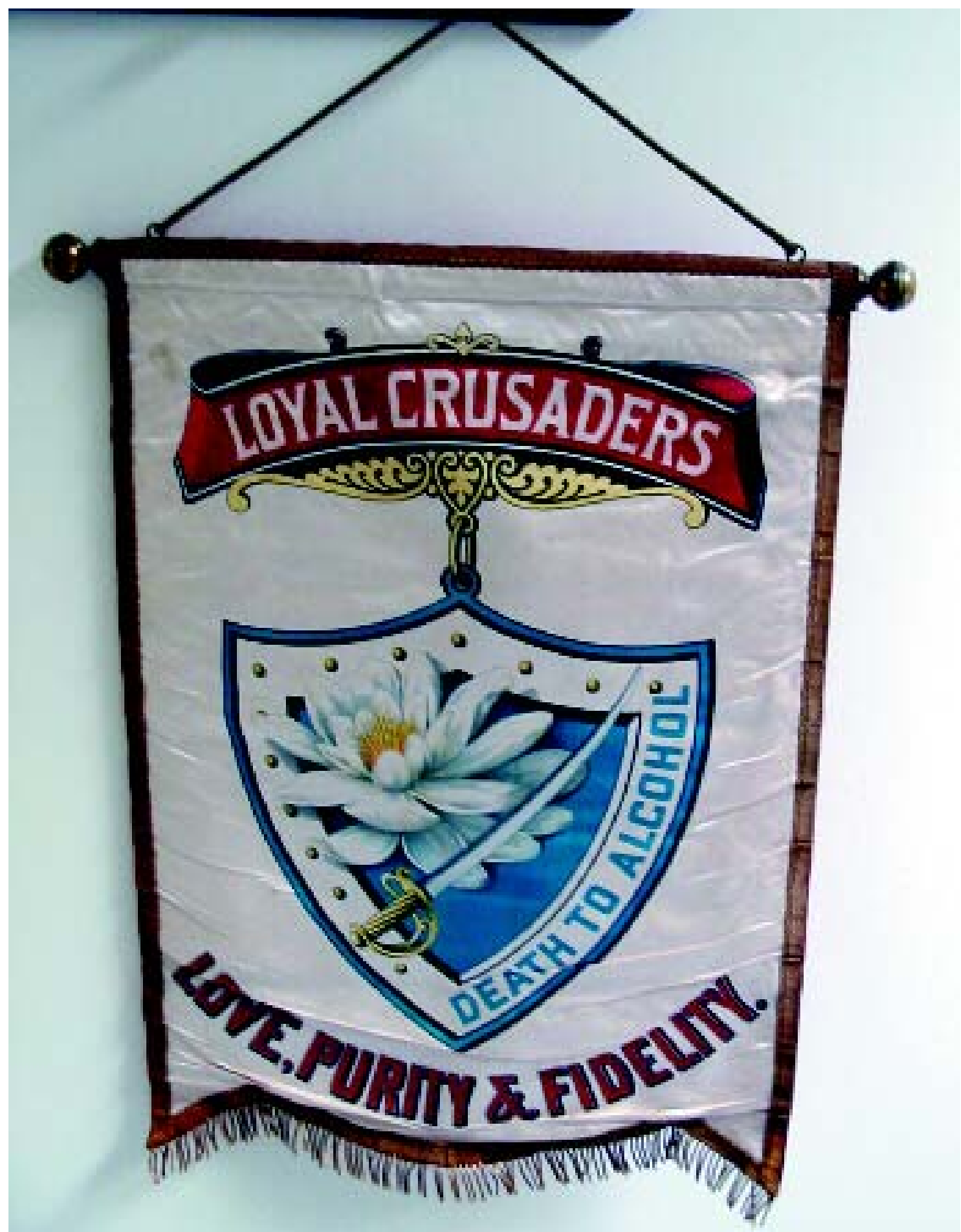

Figure 5.5 Banner from the Nova Scotia chapter of the Sons of Temperance (from Alcohol History Collection, Alcohol Studies Library) 


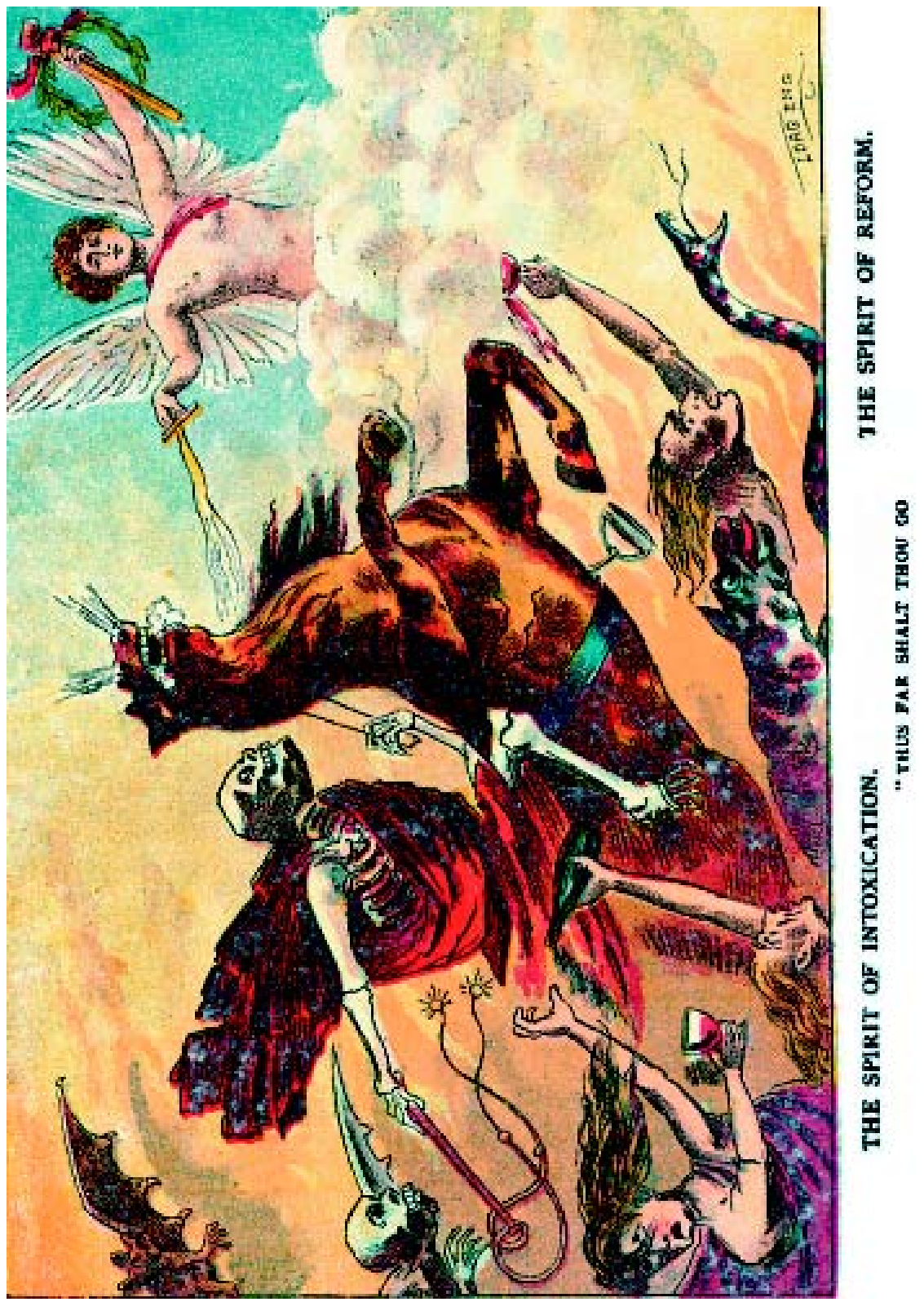

Figure 5.6 "The Spirit of Intoxication; The Spirit of Reform," one of the more colorful temperance illustrations from Broken Fetters, the Light of Ages on Intoxication (from Alcohol History Collection, Alcohol Studies Library) 
in the Research Libraries Information Network (RLIN) database. We added note fields to hold other kinds of information that might be useful for searching the contents of the materials in the collection. In view of the nature of the collection, searchable fields for format and condition of material were created using controlled vocabulary lists.

Perhaps the most significant decision made when creating the database was to include a searchable field for illustrations. Over the years, scholars and educators have made numerous requests to the center library for historical images - pictures of temperance leaders or events, or well-known illustrations from the time period. Until the Alcohol History Database, there was no easy way to locate illustrations. In addition to including some actual images in the database, we wanted to provide a means of searching across the content of all illustrations to identify needed items. We created a controlled list to designate types of illustrations. Content information (for example, captions, persons, places, or events depicted) was included in the note field. Actual images were added for those illustrations not restricted by copyright or for which permission had been secured.

The Alcohol History Database provided us with an electronic catalog for the historical collection. However, it was initially limited to on-site use from the center library's local network. In order to take that all-important step to full public access, the database was mounted on the Internet in 200I. Users can now retrieve full bibliographic records, including subject headings and notes, for all materials in the collection. They can also search for images within the database itself or by browsing the "Image Library" from the opening page.

The Alcohol History Collection has evolved over the years from a loose amalgam of acquisitions and donations into an organized collection of print and graphic materials. Its companion, the Alcohol History Database, has added the extra dimension of broad public access from the Web, as well as the ability to identify and display graphic images from within the contents of the collection. It also offers digital possibilities for inclusion of some full-text material, such as pamphlets or broadsides. Together, these tools provide students and scholars with a major resource for the study of the American temperance and prohibition movements. ${ }^{16}$ 


\section{Notes}

I. Mark Edward Lender and James Kirby Martin, Drinking in America: A History, rev. ed. (New York: The Free Press, I987), 205.

2. Thomas M. Nephew et al., Apparent Per Capita Alcohol Consumption: National, State, and Regional Trends, 1977-2000, Surveillance Report no. 62 (Bethesda, MD: National Institute on Alcohol Abuse and Alcoholism, Alcohol Epidemiologic Data System, 2003), I.

3. The author searched the multi-library catalogs of the Online Computer Library Center (OCLC) and the Research Libraries Information Network (RLIN) to compare title holdings.

4. Daniel Tauvry, Pratique des maladies aigues: Et de toutes celles qui dependent de la fermentation des liqueurs, 2nd ed. (Paris: Chez Laurent d'Houry, I706-I707).

5. Peter Paxton, A Directory Physico-Medical, Compos'd for the Use and Benefit of All Such as Design to Study and Practise the Art of Physick. Wherein Proper Methods and Rules are Prescrib'd and Catalogues of Such Authors Exhibited, as are Necessary to be Consulted by All Young Students(London: J. Sprint, I707).

6. United States Circuit Court of Appeals (2nd Circuit), United States of America, Appellee, vs. Louis E. Thibault, Defendant-Appellant. Brief for the Appellant (New York: The Ballou Press, 1930).

7. John Harvey Kellogg, Dr. Kellogg's Temperance Charts (Battle Creek, MI: Health Publishing, I882). "Showing in a series of ten plates, the physical effects of alcohol and tobacco" (from plate no. I). Content of plates: I. "The Alcohol Family (Physical Properties of Methyl, Ethyl, Butyl, and Amyl Alcohols)"; 2. "A Healthy Stomach"; 3. "Stomach of a Moderate Drinker"; 4. "Stomach of a Hard Drinker"; 5. "Stomach of Delirium Tremens"; 6. "Cancer of the Stomach"; 7. "Blood, Cells, and Nerve Fiber of a Drunkard"; 8. "A Drunkard's Heart and Brain (plus Smoker's Cancer and Rum Blossom)"; 9. "Healthy and Diseased Organs (Lung, Kidney, Liver, Eye)"; IO. "Effects of Alcohol and Tobacco on the Pulse."

8. Mark Edward Lender and Karen R. Karnchanapee, Temperance Tales and the Alcoholic: Creation of a Stereotype, I850-I930 (New Brunswick, NJ: Journal of Studies on Alcohol, 1979). Slides, audiotape, discussion guide. 
9. Rutgers University Center of Alcohol Studies, Alcohol History Database, http://www.scc.rutgers.edu/alcohol_history/.

I0. Center on Alcohol and Addiction Studies, Brown University, Alcohol and Addiction Studies: A Guide to Resources at Brown, http:// www.brown.edu/Facilities/University_Library/libs/hay/collections/ kirk/index.html.

I I. The Anti-Saloon League Museum is maintained by the Westerville, Ohio, Public Library. Excerpts from the collection have been digitized on its website: http://www.wpl.lib.oh.us/AntiSaloon/.

12. The catalog for the Hagley Library is available on its website: http:/ /www.hagley.lib.de.us/index. html.

I3. Library of Congress, American Memory: Historical Collections for the National Digital Library, online at http://memory.loc.gov/ ammem/ammemhome.html.

I4. National Library of Medicine, Images from the History of Medicine, online at http://wwwihm.nlm.nih.gov/.

I5. To learn more about the history and development of the Center of Alcohol Studies, see two essays by Penny Booth Page, "Yale Center of Alcohol Studies" and "Rutgers Center of Alcohol Studies," in Alcobol and Temperance in Modern History: An International Encyclopedia, ed. Jack S. Blocker, Ian R. Tyrell, and David M. Fahey (Santa Barbara, CA: ABCCLIO, 2003). For more information on the development of the center's library, see Catherine Weglarz, "Rutgers Center of Alcohol Studies Library: A Brief History," Journal of the Rutgers University Libraries 52, no. I (1990): 7-I6.

16. For additional information about historical materials on alcohol and temperance, see Donald A. Sinclair, Demon Rum: A Bibliography of Publications about Liquor and New Jersey, 1779-1932; Mostly Controversial Publications Relating to the Liquor Problem, Temperance Addresses, Tracts, Reports, Liquor Laws, etc. (New Brunswick NJ: Rutgers Special Collections and University Archives, 1996). This bibliography lists more than 400 items from collections at Rutgers and other New Jersey locations, as well as the Library of Congress, University of Illinois, and Yale. For information about online resources on temperance and prohibition, see Penny B. Page and Valerie Mead, Historical Resources on Alcohol Use in America (Piscataway, NJ: Rutgers University Center of Alcohol Studies, 2000), http://www.rci.rutgers.edu/ cas2/histsites.shtml. 